\title{
Scales of spatial variation in Mediterranean subtidal sessile assemblages at different depths
}

\author{
Antonio Terlizzi ${ }^{1, *}$, Marti J. Anderson ${ }^{2}$, Simonetta Fraschetti ${ }^{1}$, \\ Lisandro Benedetti-Cecchi ${ }^{3}$ \\ ${ }^{1}$ Laboratorio Zoologia e Biologia Marina, Dipartimento di Scienze e Tecnologie Biologiche ed Ambientali, \\ Università di Lecce, CoNISMa, 73100 Lecce, Italy \\ ${ }^{2}$ Department of Statistics, University of Auckland, Private Bag 92019, Auckland, New Zealand \\ ${ }^{3}$ Dipartimento di Scienze dell'Uomo e dell'Ambiente, Università di Pisa, Via A. Volta 6, 56126 Pisa, Italy
}

\begin{abstract}
Analyses of spatial patterns of distribution of populations and assemblages along environmental gradients are common in marine ecology. How these patterns vary at different spatial scales has seldom been examined, despite the fact that patterns in nature are intrinsically scaledependent. This study quantified variability in subtidal assemblages at a hierarchy of spatial scales along a depth gradient, using several univariate and multivariate techniques. Despite variation in the sizes of depth effects in time and space, there were large, significant and generally characterisable differences in the structure of assemblages at different depths. The sizes of multivariate and univariate components of variation at different spatial scales were compared at each of 3 different depths $(5,15$ and $25 \mathrm{~m})$, using a bias-corrected bootstrapping approach. The sizes of variance components at different spatial scales varied with depth and choice of transformation. In all cases, the largest component of variation was at the smallest scale (tens of centimeters). A pattern of decreasing residual variance with depth was seen for untransformed data, while a pattern of increasing residual variance with depth was seen for presence/absence data. In contrast, variation among locations (separated by $>1 \mathrm{~km}$ ) and among sites (separated by hundreds of metres) was largest at intermediate depths $(\sim 15 \mathrm{~m})$, regardless of the transformation used. The multivariate procedures used here offer several advantages over previously used techniques, providing suitable quantitative methods for analysing, at multiple scales, the patchy and complex nature of rocky subtidal assemblages.
\end{abstract}

KEY WORDS: Depth gradient - Hierarchical analyses - Spatial scales · Variance components · Bootstrap $\cdot$ Subtidal sessile assemblages

Resale or republication not permitted without written consent of the publisher

\section{INTRODUCTION}

The notion of heterogeneity in nature is intrinsically dependent on the scale of measurement (e.g. Andrew \& Mapstone 1987, Levin 1992, Underwood \& Petraitis 1993). Variation in assemblage structure is consequently more evident at particular scales than at others (Wiens et al. 1993), bringing important ecological insights to basic and applied ecology (Underwood et al. 2000). First, as different processes are likely to operate differently in space and time, the identification of relevant scales of variation is a necessary prerequisite before explanatory models can be proposed and tested
(Andrew \& Mapstone 1987). Second, investigating patterns at hierarchies of scales can help in determining the extent to which small-scale processes can be generalised (Underwood \& Petraitis 1993, Lawton 1996) and whether local processes may be scaled up to generate patterns on wider scales (Wootton 2001). Third, especially in the case of highly variable systems, identifying the relevant scales of variation allows for more reliable predictions of anthropogenic impacts (Bishop et al. 2002) and provides information necessary for the determination of managerial conservation units and/or the design of marine protected areas (Benedetti-Cecchi et al. 2003, Botsford et al. 2003, Fraschetti et al. 2005a). 
Traditionally, ecologists have examined spatial patterns of distribution of populations and assemblages along sharp gradients of environmental variables (Horne \& Schneider 1995). For instance, the paradigm of marine benthic zonation (Stephenson \& Stephenson 1949, Witman \& Dayton 2001) has explained the vertical distribution of organisms in relation to the most obvious gradients of emersion and desiccation in intertidal (Southward 1958) as well as light and water movement in subtidal (Riedl 1971, Pérès 1982) habitats. Vertical zonation, however, cannot explain all of the variability in spatial patterns (Benedetti-Cecchi 2001). Other sources of variation require proper quantification before any conclusion about the vertical distribution of communities can be drawn (Underwood 2000). The focus on the most obvious physical spatial gradients can distract from other important sources of variation (e.g. horizontal variation within any particular level of the gradient, and temporal changes in patterns of distribution). One possible strategy is to carry out multi-scale analyses of variation. This approach encompasses a wider range of potential ecological processes than those that would be targeted by focusing on a single gradient.

The analysis of spatial patterns at hierarchies of spatial and temporal scales is also a logical means of avoiding spatial and temporal confounding (Hurlbert 1984). It also provides tests of generality for models. Despite the potential importance of this approach, considerations of time, available resources and logistics have traditionally limited its adoption and there are few examples of studies that have tested the consistency of patterns along sharp environmental gradients at hierarchies of spatial scales (see Benedetti-Cecchi 2001 as an example from intertidal Mediterranean rocky sea shores).

Testing hypotheses about spatial and temporal patterns of variability of assemblages across scales is methodologically complex (Rossi et al. 1992, Underwood \& Chapman 1996, 1998, Legendre \& Anderson 1999, Benedetti-Cecchi 2001, Perry et al. 2002). Recent advances in multivariate methods allow the analysis of multivariate data sets in structured, multifactorial designs. Such methods are not restricted to use with metric distance measures and allow partitioning of data according to any ANOVA design (Legendre \& Anderson 1999, Anderson 2001a,b, McArdle \& Anderson 2001). These techniques are suitable for the analysis of patterns in assemblages across multiple spatial scales (Anderson \& Millar 2004, Fraschetti et al. 2006).

The aim of the present study was to conduct a mensurative experiment (sensu Hurlbert 1984) in order to examine distributional patterns of subtidal sessile assemblages along the south coast of Italy. We used a structured hierarchical design to quantify the magnitude of variation attributable to each of several spatial scales at each of 3 positions along the depth gradient $(5,15$, and $25 \mathrm{~m})$.

In nested designs, such as the one used in this study, spatial and temporal scales are chosen arbitrarily. This contrasts with other approaches in which variability is measured continuously in space and/or in time. The advantages and disadvantages of each approach have been debated widely in the literature (see Rossi et al. 1992 and Underwood \& Chapman 1996 for thorough discussion). The hierarchical sampling design provides independent, unbiased and rigorous quantitative measures of variability for each of a number of chosen spatial scales and can be implemented over much larger areas. In contrast, continuous sampling of surfaces presents fewer problems regarding the imposition of arbitrarily chosen scales and allows characterisation of scales along continuous gradients, but for any one sampling effort it is limited in its spatial extent (Underwood \& Chapman 1998). Our choice of a nested design was dictated by the impossibility of sampling the entire study area continuously. Furthermore, it was not a goal of this study to try to quantify and characterise spatial variation at all intermediate spatial scales, as is commonly done using analytical techniques such as correlograms and variograms (Legendre \& Fortin 1989). In the present study, spatial scales known to be relevant sources of variability for sessile marine assemblages (e.g. Fraschetti et al. 2001) were deliberately selected to compare estimates of variance components obtained for each of those scales among the 3 depths.

We provide explicit comparisons of sizes of multivariate or univariate variance components using bootstrap confidence intervals on differences for various positions along the depth gradient (e.g. Efron \& Tibshirani 1993). This is the first use of such bootstrapping techniques on dissimilarity-based multivariate data to assess variability, and it is applied to provide new insights into assemblage heterogeneity in these subtidal environments. This paper therefore has 2 primary aims: (1) to describe and quantify spatial variation in subtidal assemblages along a strong ecological gradient (depth) at different spatial scales and (2) to demonstrate the use of these analytical methods in ecological studies.

\section{MATERIALS AND METHODS}

Study area and sampling design. The study area is situated along the southeastern coast of Apulia (Adriatic and Ionian Seas, SE Italy; Fig. 1). The area is characterised by wave-exposed rocky cliffs extend- 


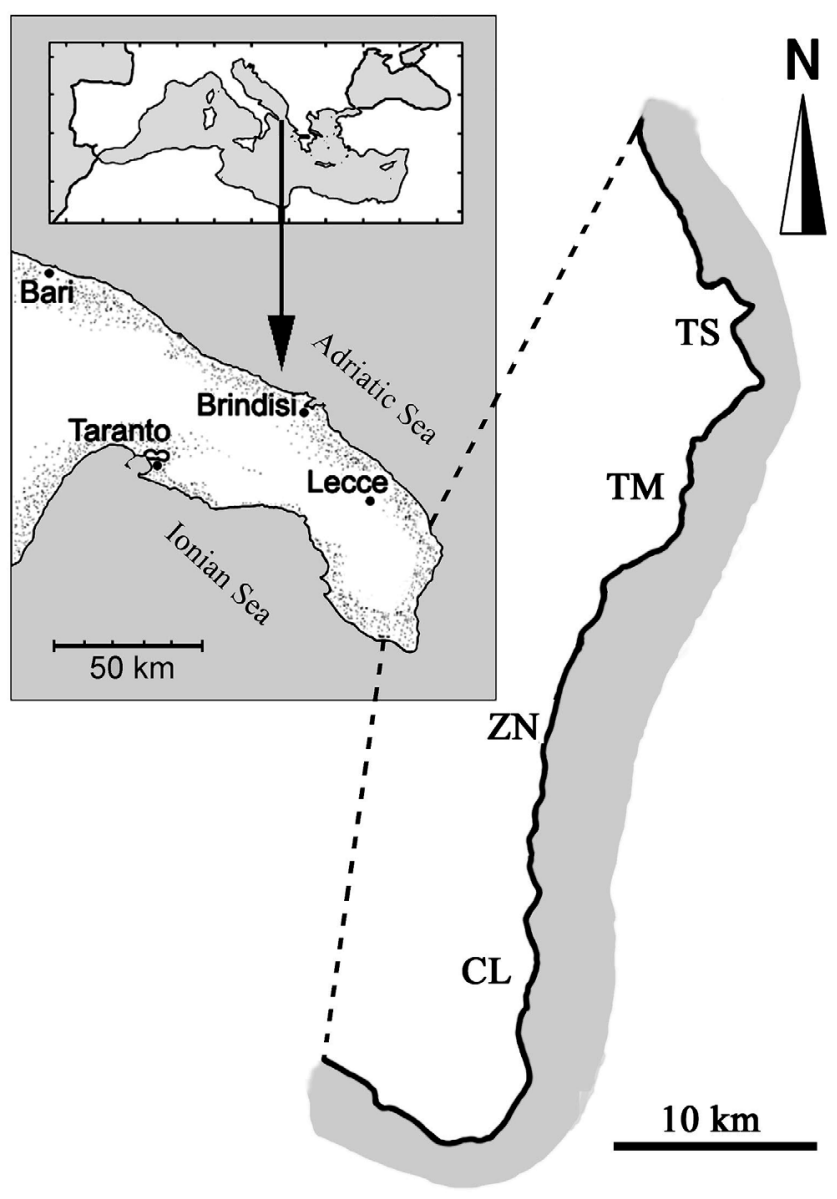

Fig. 1. Study area and position of locations: TS = Torre del Serpe; $\mathrm{TM}=$ Torre Minervino; $\mathrm{ZN}=$ Zinzulusa $; \mathrm{CL}=$ Ciolo

ing abruptly from the surface to a depth of about $30 \mathrm{~m}$. From the surface to about $15 \mathrm{~m}$ depth, the rocky substrate consists of a mosaic of barrens and patches dominated by erect and encrusting algae, hydroids, encrusting bryozoans and sponges. Deeper than this, the substrate consists of so-called 'coralligenous formations' (CFs), a term broadly defining the secondary hard substrates formed by bioconstructors (e.g. calcareous encrusting algae, bryozoans, serpulids, etc.) and the biota inhabiting them (Sarà 1969, Virgilio et al. 2006). Below $30 \mathrm{~m}$, the substrate is gently sloping and CFs alternate with sandy patches.

Four locations, namely Torre del Serpe (TS), Torre Minervino (TM), Zinzulusa (ZN), and Ciolo (CL) (Fig. 1), each 500 to $600 \mathrm{~m}$ in length along the shoreline, were randomly selected from a set of possible locations separated by at least $3 \mathrm{~km}$ and characterised by similar slope, type of substrate and wave exposure. Three sites (separated by at least $100 \mathrm{~m}$ ) were selected at random within each location, and for each site sampling was undertaken at 5, 15 and $25 \mathrm{~m}$ depth.
Sampling was repeated on 4 randomly selected occasions, at least 2 mo apart, over a period of 15 mo (May and July 2000, February and July 2001, referred to as T1, T2, T3 and T4, respectively). Ten randomly located surfaces of $16 \times 23 \mathrm{~cm}$ were sampled photographically (using a Nikonos V underwater camera, $28 \mathrm{~mm}$ focal length, close-up macro system and $2 \mathrm{SB}$ 105-Nikon strobes) at each depth and site, yielding a total of 1440 units of observation.

Analysis of slides and taxonomic discrimination. The slides were analysed under a binocular microscope by superimposing a grid of 24 equally sized squares. Percent cover values of sessile organisms (algae and invertebrates) were determined visually by scoring each taxon in each square as follows: $0=$ absence, $1=\sim 25 \%$ cover, $2=\sim 50 \%$ cover, $3=\sim 75 \%$ cover and $4=$ virtually the whole square. Organisms filling less than $1 / 4$ square were given an arbitrary value of 0.5. Scores for all 24 squares were added up, and final values expressed as percentages (Dethier et al. 1993). Motile animals (e.g. gastropods, ophiuroids and amphipods) were not counted. Destructive samples were also collected and specialists assisted in identification of organisms at the lowest practicable taxonomic level. Details of the variables recorded are reported in Appendix 1 (available as Supplementary Material at www.int-res.com/articles/suppl/m332p025_app.pdf).

Statistical analyses. Multivariate analyses:The design consisted of 4 factors: Time ( $\mathrm{T} ; 4$ levels, random), Location ( $\mathrm{L}_{;} 4$ levels, random, crossed with Time), Site ( $\mathrm{S}_{\text {; }}$ 3 levels, random, nested in Location, crossed with Time) and Depth (D; 3 levels [5, 15 and $25 \mathrm{~m}$ ], fixed, crossed with Time, Location and Site), with $\mathrm{n}=10$ replicate observations per combination of factors. There were 79 variables (taxa) included in multivariate analyses. First, a distance-based permutational MANOVA (PERMANOVA, Anderson 2001a, McArdle \& Anderson 2001) was performed on the full design, with 4999 random permutations of appropriate units (Anderson 2001b), using the computer programme PERMANOVA (freely available from www.stat.auckland.ac.nz/ mja/ Programs.htm). When there were too few possible permutations to obtain a reasonable test, a p-value was calculated using 4999 Monte Carlo draws from the appropriate asymptotic permutation distribution (Anderson \& Robinson 2003). All analyses were based on Bray-Curtis dissimilarities on $\log _{10}(x+1)$-transformed data. This transformation placed all taxa within the same range of abundance values, giving similar weight to differences in composition and abundance to the final measure of dissimilarity (Clarke \& Green 1998).

Terms significant in the full model were examined individually using appropriate pairwise comparisons and non-metric multidimensional scaling (nMDS) plots of the fixed factor (Depth), within levels of the other fac- 
tors (i.e. in the case of interaction terms, see 'Results'). To examine generality of patterns in assemblages with depth, we also examined nMDS plots of centroids for each Site within each combination of Time, Location and Depth (obtained using averages from principal coordinate axes of the observations $(n=10)$, see McArdle \& Anderson 2001 for details). All nMDS plots were obtained using the PRIMER computer programme (Plymouth Marine Laboratory, UK).

As depth was found to show a strong single gradient across the full set of observations (see 'Results'), a single canonical analysis of principal coordinates (CAP, Anderson \& Willis 2003, Anderson \& Robinson 2003) was performed for the factor of Depth. Distinctness of groups was assessed using leave-one-out allocation success (Anderson \& Robinson 2003). Individual taxa that might be responsible for any group differences seen in the CAP plot were investigated by calculating product-moment correlations of original variables with canonical ordination axes (e.g. Anderson \& Willis 2003). These correlations of individual variables (taxa) with the 2 canonical axes $\left(r_{1}\right.$ and $\left.r_{2}\right)$ were then plotted as arrows in a biplot. Only those taxa having relatively strong correlations (i.e. with an arrow length of $\sqrt{r_{1}^{2}+r_{2}^{2}} \geq 0.2$ were included in the plot.
It was also of interest to compare the 3 depths in terms of their spatio-temporal variability at various scales. For the multivariate data, this was done by performing an analysis of the 3 random factors (Time, Location and Site) and their interactions separately for each Depth (using PERMANOVA). The multivariate pseudo variance components for each term in the model were then calculated using direct multivariate analogues to the univariate ANOVA estimators (e.g. Searle et al. 1992). In the event that an estimator resulted in a negative value, multivariate analogues to the restricted maximum likelihood (REML) estimators were used (Searle et al. 1992, Fletcher \& Underwood 2002). A complete outline of the ANOVA estimators used for the model, based on expected values of mean squares for all situations, is given in Table 1. For the multivariate case, the sums of squares are interpretable as sums of squared dissimilarities (Anderson 2001a), therefore the values of pseudo multivariate variance components can be interpreted as the average squared dissimilarity among the units or levels of that random factor. In addition, the square root of each component (like a standard deviation in the univariate case) is interpretable in terms of the units of the original dissimilarity measure (e.g. Anderson et al. 2005).

Table 1. Expected values for mean squares and estimators of variance components for the 3-factor model, analysed separately at each depth. Here, $\mathrm{a}=4$ (number of times), $\mathrm{b}=4$ (number of locations), $\mathrm{c}=3$ (number of sites) and $\mathrm{n}=10$ (number of replicates). $\mathrm{SS}=\mathrm{sums}$ of squares; MS $=$ indicates mean squares and $\mathrm{df}=$ degrees of freedom. Further details are given in a footnote for each term in the model to identify the estimators in the event that one or more of the components was estimated at zero

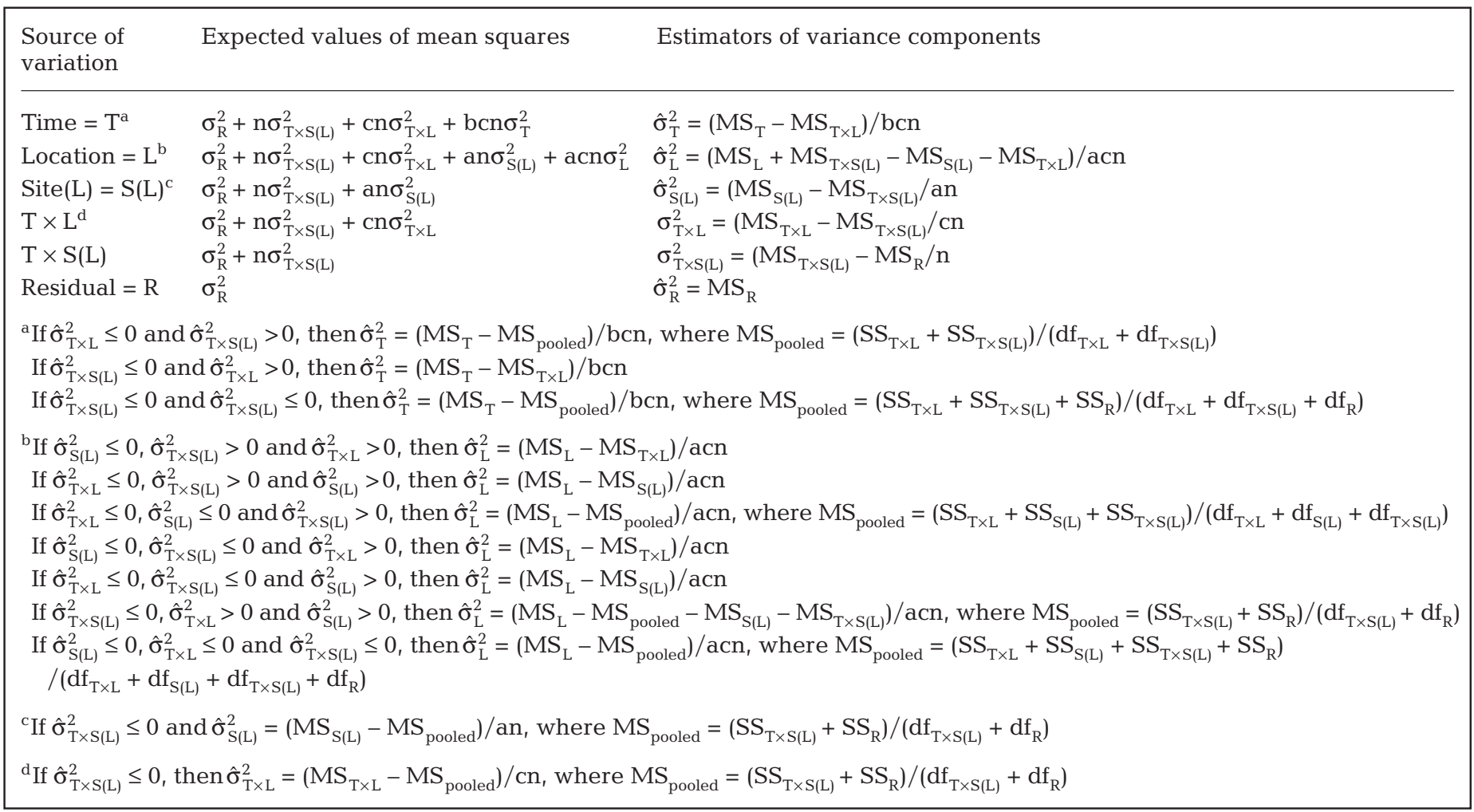


Comparisons among the 3 depths in the values of their estimated variance components were obtained by calculating the $95 \%$ confidence intervals for the pairwise differences in these estimates using bootstrapping (Efron \& Tibshirani 1993). Bootstrap data were obtained by sampling randomly and by replacing first a Time, then a Location and then a Site, keeping the individual observations within a cell together (Davison \& Hinkley 1997). Bias-corrected confidence intervals were obtained for the 0.025 and 0.975 percentiles of the bootstrap distribution of 5000 samplings (Efron \& Tibshirani 1993). Confidence intervals that did not include zero provided evidence for a difference between the 2 depths being compared. All bootstrap confidence intervals were calculated using a specialpurpose computer programme written in FORTRAN by M. J. Anderson.

To understand how different components of the assemblage (i.e. relatively abundant versus rarer taxa) may provide different information with respect to estimated multivariate pseudo variance components at different depths, we compared the bootstrap variance components for several different transformations of the multivariate data: no transformation, transformation to $\log _{10}(x+1)$ and presence/absence.

Univariate analyses: Analysis of variance was used to examine spatial patterns for single taxa. The model of analysis was the same as that described for the multivariate case. When appropriate, Student-NewmanKeuls (SNK) tests were carried out for post hoc multiple comparisons of the means. Anderson's test (Winer et al. 1991) was used to test for differences in the frequency with which depths were given a particular rank by SNK tests in a series of multiple comparisons. These tests were applied to those subsets of multiple comparisons that unequivocally ranked a particular depth as the first or the lowest in the sequence. Cochran's $C$-test was employed to examine homogeneity of variances. Analyses were performed on untransformed data when variances were homogeneous, otherwise transformations were applied to the original data, as indicated in tables.

Variance components were obtained using REML estimators (Searle et al. 1992). To test the hypothesis that patterns in spatial and temporal variances of single taxa differed among depths, the same bootstrap procedure described for the multivariate case was employed. These analyses were performed on untransformed data.

\section{RESULTS}

\section{Multivariate analyses}

Effects of depth on assemblages varied from site to site and from time to time as evidenced by the significant $\mathrm{T} \times \mathrm{D} \times \mathrm{S}(\mathrm{L})$ interaction term (Table 2). Pairwise comparisons of assemblages at the 3 different depths within each $\mathrm{T} \times \mathrm{S}(\mathrm{L})$ combination $(48$ sets of 3 tests each) revealed 2 comparisons (15 vs. $25 \mathrm{~m}$ ) which were not statistically significant $(0.05<\mathrm{p}<0.10)$ and 7 comparisons which were significant at the 0.05 level $(0.01<$ $\mathrm{p}<0.05$ ); all other tests (135 out of 144) were significant at the 0.01 level $(\mathrm{p}<0.01)$. Individual nMDS plots for each $\mathrm{T} \times \mathrm{S}(\mathrm{L})$ comparison (Appendix 2, available as Supplementary Material at www.int-res.com/articles/ suppl/m332p025_app.pdf) support these general results. Although the effects of depth were generally clear, there were particular locations and times where the dif-

Table 2. Permutational MANOVA on the basis of the Bray-Curtis dissimilarities on $\log (x+1)$-transformed abundance data from 79 variables (taxa, see Appendix 1). Each test was based on 4999 permutations of appropriate units. The term used for the denominator mean square is given in the column $\mathrm{MS}_{\text {denom. }}$. The appropriate permutable units are indicated by the denominator mean square in each case and are shown in the final column (see Anderson \& ter Braak 2003 for details). No single denominator was available to construct appropriate tests for D, L or D $\times$ L, so these tests were not performed (indicated by 'No test')

\begin{tabular}{|c|c|c|c|c|c|c|c|}
\hline $\begin{array}{l}\text { Source } \\
\text { of variation }\end{array}$ & df & SS & MS & $F$ & $\mathrm{P}($ perm $)$ & $\mathrm{MS}_{\text {denom }}$ & $\begin{array}{l}\text { Permutable } \\
\text { units }\end{array}$ \\
\hline Time $=\mathrm{T}$ & 3 & 131613.830 & 43871.277 & 4.750 & 0.000 & $\mathrm{~T} \times \mathrm{L}$ & $16 \mathrm{~T} \times \mathrm{L}$ cells \\
\hline Depth $=\mathrm{D}$ & 2 & 530021.783 & 265010.891 & No test & & & \\
\hline Location = L & 3 & 153813.322 & 51271.107 & No test & & & \\
\hline Site $(L)=S(L)$ & 8 & 43383.401 & 5422.925 & 1.551 & 0.017 & $\mathrm{~T} \times \mathrm{S}(\mathrm{L})$ & $48 \mathrm{~T} \times \mathrm{S}(\mathrm{L})$ cells \\
\hline $\mathrm{T} \times \mathrm{D}$ & 6 & 62683.801 & 10447.300 & 2.203 & 0.010 & $\mathrm{~T} \times \mathrm{D} \times \mathrm{L}$ & $48 \mathrm{~T} \times \mathrm{D} \times \mathrm{L}$ cells \\
\hline $\mathrm{T} \times \mathrm{L}$ & 9 & 83122.007 & 9235.779 & 6.641 & 0.000 & $\mathrm{D} \times \mathrm{S}(\mathrm{L})$ & $48 \mathrm{D} \times \mathrm{S}(\mathrm{L})$ cells \\
\hline $\mathrm{T} \times \mathrm{S}(\mathrm{L})$ & 24 & 83918.649 & 3496.610 & 2.860 & 0.000 & Residual & 1440 raw data units \\
\hline $\mathrm{D} \times \mathrm{L}$ & 6 & 137685.333 & 22947.555 & No test & & & \\
\hline $\mathrm{D} \times \mathrm{S}(\mathrm{L})$ & 16 & 98869.301 & 6179.331 & 2.012 & 0.000 & $\mathrm{~T} \times \mathrm{D} \times \mathrm{S}(\mathrm{L})$ & $144 \mathrm{~T} \times \mathrm{D} \times \mathrm{S}(\mathrm{L})$ cells \\
\hline $\mathrm{T} \times \mathrm{D} \times \mathrm{L}$ & 18 & 85357.295 & 4742.072 & 1.544 & 0.003 & $\mathrm{~T} \times \mathrm{D} \times \mathrm{S}(\mathrm{L})$ & $144 \mathrm{~T} \times \mathrm{D} \times \mathrm{S}(\mathrm{L})$ cells \\
\hline $\mathrm{T} \times \mathrm{D} \times \mathrm{S}(\mathrm{L})$ & 48 & 147403.279 & 3070.902 & 2.512 & 0.000 & Residual & \\
\hline Residual & 1296 & 1584552.990 & 1222.649 & & & & \\
\hline Total & 1439 & 3142424.991 & & & & & \\
\hline
\end{tabular}


ferences were less distinct (e.g. Time 2, Location TS, Sites 2 and 3; Appendix 2). Thus, effects of depth within sites were generally strong, with clear differences between 5 and $25 \mathrm{~m}$ always detected, but the relative sizes of these effects varied.

At a larger scale (within locations rather than sites), there was also a significant $\mathrm{T} \times$ $\mathrm{D} \times \mathrm{L}$ interaction (Table 2). At Location TS, there were no significant differences detected between assemblages at 5 and those at $15 \mathrm{~m}$, nor between those at 15 and those at $25 \mathrm{~m}$ (Table 3). No significant differences were found between assemblages at 15 and $25 \mathrm{~m}$ for Location TM either. More consistent significant differences among all depths were found at the 2 southern Locations CL and ZN. Non-metric MDS plots of site centroids for each time generally showed a strong depth gradient, with clear differences between assemblages at 5 and $25 \mathrm{~m}$ (Fig. 2). However, differences among locations were not evident from these 2-factor plots (Fig. 2).

An overall nMDS plot of site centroids for all locations, times and depths demon-
Table 3. Multivariate pairwise comparisons among the 3 depths $(5,15,25 \mathrm{~m})$ at each location and time (following the significant $\mathrm{T} \times \mathrm{D} \times \mathrm{L}$ interaction term in Table 2) on the basis of the Bray-Curtis dissimilarities on $\log (x+1)$ transformed data, with the $\mathrm{p}$-value for each test obtained using a Monte Carlo draw from the asymptotic permutation distribution (see Anderson \& Robinson 2003 for details). This approach was used because there are only 10 possible permutations of the appropriate $\mathrm{T} \times \mathrm{D} \times \mathrm{S}(\mathrm{L})$ units (i.e. the $\mathrm{n}=10$ replicates need to be kept together and permuted as a unit, thus there were only 3 units per site). No corrections for multiple tests have been applied. For location abbreviations see Fig. 1

\begin{tabular}{|lccccccc|}
\hline \multirow{2}{*}{ Location } & Time & \multicolumn{2}{c}{$5 \mathrm{~m}$ vs. $15 \mathrm{~m}$} & \multicolumn{2}{c}{$5 \mathrm{~m}$ vs. $25 \mathrm{~m}$} & \multicolumn{2}{c|}{$15 \mathrm{~m}$ vs. $25 \mathrm{~m}$} \\
& & $t$ & $\mathrm{p}$ & $t$ & $\mathrm{p}$ & $t$ & $\mathrm{p}$ \\
\hline $\mathrm{TS}$ & 1 & 1.858 & 0.059 & 2.491 & 0.015 & 1.580 & 0.089 \\
$\mathrm{TS}$ & 2 & 1.193 & 0.274 & 2.159 & 0.024 & 1.218 & 0.258 \\
$\mathrm{TS}$ & 3 & 1.640 & 0.080 & 2.489 & 0.017 & 0.857 & 0.545 \\
$\mathrm{TS}$ & 4 & 1.563 & 0.109 & 1.675 & 0.075 & 0.935 & 0.474 \\
$\mathrm{TM}$ & 1 & 1.929 & 0.046 & 3.222 & 0.008 & 1.754 & 0.070 \\
$\mathrm{TM}$ & 2 & 3.220 & 0.007 & 3.299 & 0.005 & 1.485 & 0.130 \\
$\mathrm{TM}$ & 3 & 1.999 & 0.040 & 3.179 & 0.005 & 1.782 & 0.074 \\
$\mathrm{TM}$ & 4 & 2.419 & 0.014 & 3.179 & 0.009 & 1.508 & 0.128 \\
$\mathrm{CL}$ & 1 & 4.085 & 0.003 & 3.327 & 0.006 & 1.648 & 0.100 \\
$\mathrm{CL}$ & 2 & 3.380 & 0.006 & 3.787 & 0.006 & 2.429 & 0.016 \\
$\mathrm{CL}$ & 3 & 2.768 & 0.010 & 3.655 & 0.005 & 1.970 & 0.046 \\
$\mathrm{CL}$ & 4 & 2.979 & 0.011 & 3.628 & 0.005 & 1.830 & 0.051 \\
$\mathrm{ZN}$ & 1 & 1.977 & 0.039 & 3.372 & 0.004 & 2.457 & 0.018 \\
$\mathrm{ZN}$ & 2 & 2.394 & 0.019 & 4.371 & 0.002 & 4.211 & 0.003 \\
ZN & 3 & 2.715 & 0.012 & 3.453 & 0.004 & 2.578 & 0.023 \\
ZN & 4 & 2.796 & 0.013 & 3.781 & 0.003 & 2.577 & 0.017 \\
\hline
\end{tabular}
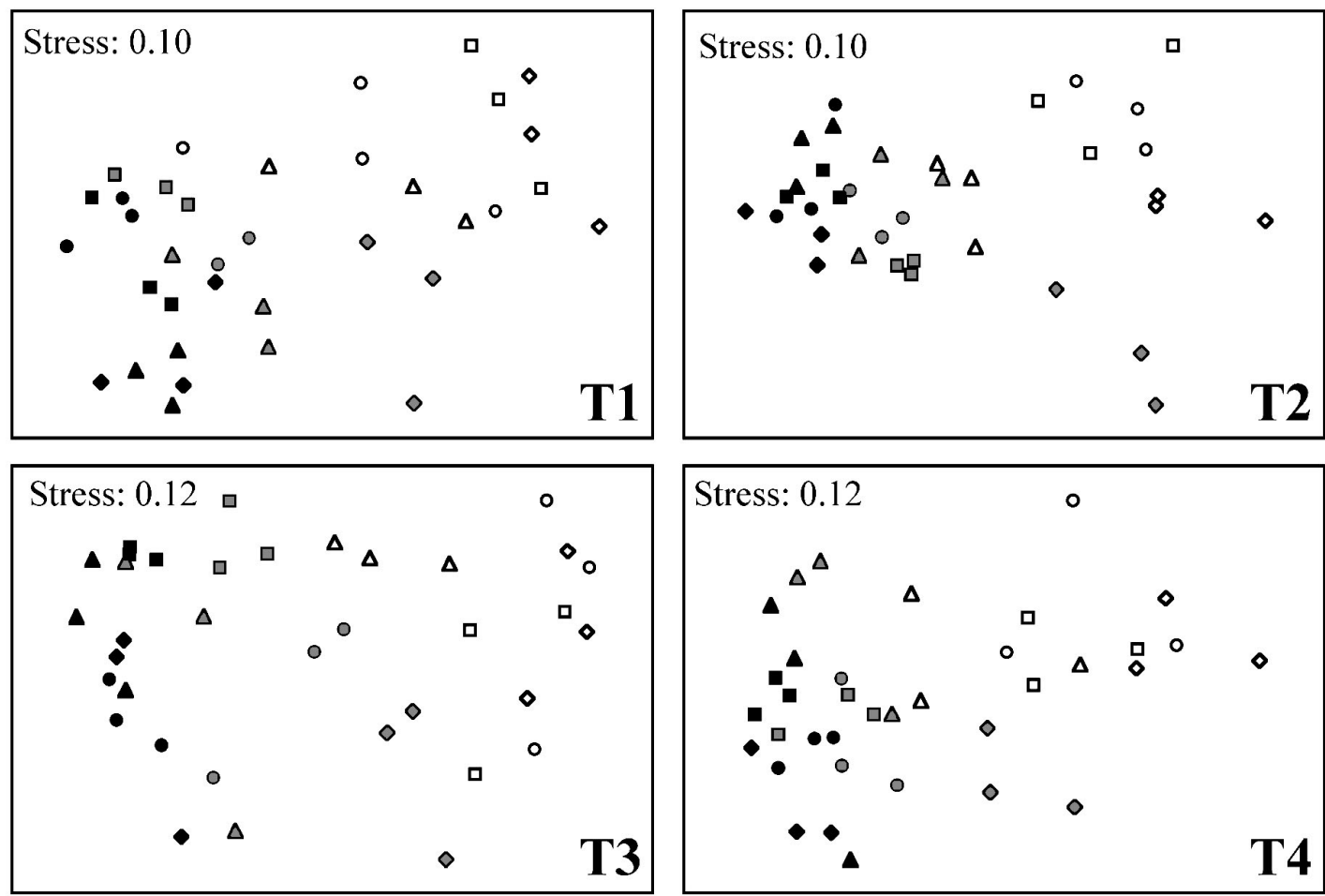

Fig. 2. Two-factor non-metric MDS plots among centroids of $\mathrm{n}=10$ observations based on the Bray-Curtis dissimilarities on $\log _{10}(x+1)$-transformed data showing the patterns of differences among assemblages at different locations $(\Delta=\mathrm{TS} ; O=\mathrm{TM} ; \square=$ ZN and $\diamond=C L$, for abbreviations see Fig. 1 ) and different depths (white symbols $=5 \mathrm{~m}$; grey symbols $=15 \mathrm{~m} ;$ black symbols $=$ $25 \mathrm{~m}$ ) at each of the 4 sampling times (T1, T2, T3, T4) 


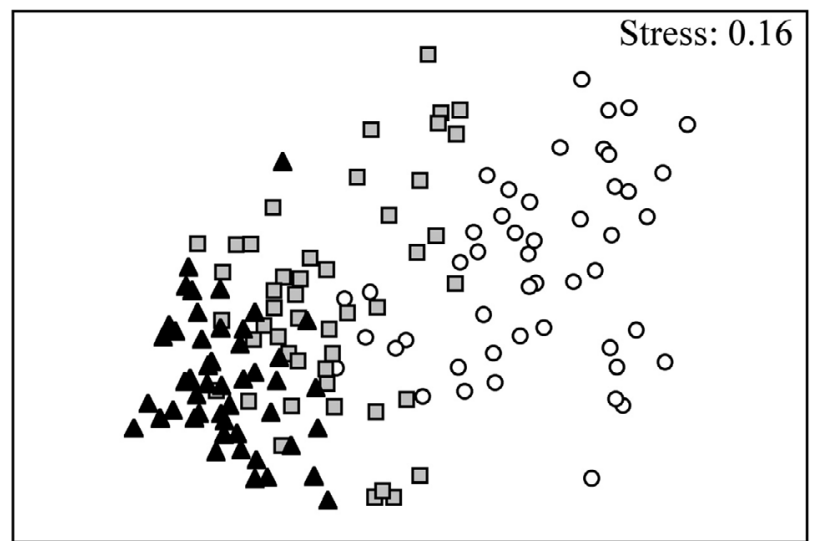

Fig. 3. Non-metric MDS plot among centroids of 10 observations based on the Bray-Curtis dissimilarities on $\log _{10}(x+1)$ transformed data showing the overall gradient of variation in

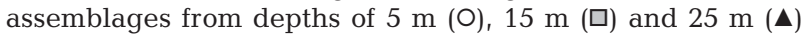

Table 4. Results of leave-one-out allocation success from the canonical analysis of principal coordinates (CAP). The analysis was done using the first $m=16$ principal coordinate axes (explaining $93.8 \%$ of the variation in the original dissimilarity matrix) based on the Bray-Curtis dissimilarities on $\log _{10}(x+1)$ transformed data. The squared canonical correlations for the 2 canonical axes were $\delta_{1}^{2}=0.90$ and $\delta_{2}^{2}=0.67$

\begin{tabular}{|c|c|c|c|c|c|}
\hline \multirow{2}{*}{$\begin{array}{l}\text { Original } \\
\text { group }\end{array}$} & \multicolumn{3}{|c|}{ Classified as: } & \multirow{2}{*}{ Total } & \multirow{2}{*}{$\%$ correct } \\
\hline & $5 \mathrm{~m}$ & $15 \mathrm{~m}$ & $25 \mathrm{~m}$ & & \\
\hline $5 \mathrm{~m}$ & 46 & 2 & 0 & 48 & 95.83 \\
\hline $15 \mathrm{~m}$ & 1 & 45 & 2 & 48 & 93.75 \\
\hline $25 \mathrm{~m}$ & 0 & 4 & 44 & 48 & $\begin{array}{r}91.67 \\
\text { Total }=93.75\end{array}$ \\
\hline
\end{tabular}

strated a clear single depth gradient, with assemblages at $5 \mathrm{~m}$ being somewhat more distinct than those at either 15 or $25 \mathrm{~m}$ (Fig. 3). This and the patterns seen in the four 2-factor plots (Fig. 2) suggest strongly that the 3 -way interaction of $\mathrm{T} \times \mathrm{D} \times \mathrm{L}$ was caused by variation in the sizes of the effects of depth, but not in their general direction in multivariate space (i.e. compositional structure).

The CAP achieved the highest allocation success $(91.2 \%)$ using $m=16$ principal coordinate axes, which themselves also explained $93.8 \%$ of the variation in the original dissimilarity matrix (Table 4 ). The 2 canonical axes (the number required to distinguish 3 groups in multivariate space) had very high canonical correlations with the multivariate assemblages $\left(\delta^{2}\right.$, Fig. 4$)$. The assemblages at $5 \mathrm{~m}$ were the most distinct, but assemblages at 15 and $25 \mathrm{~m}$ also separated quite well on the canonical plot (Fig. 4).

Several individual variables demonstrated high correlations with the canonical axes (see Table 5 for the abbreviations of the variable taxa used in Fig. $4 \mathrm{~b}$ ).
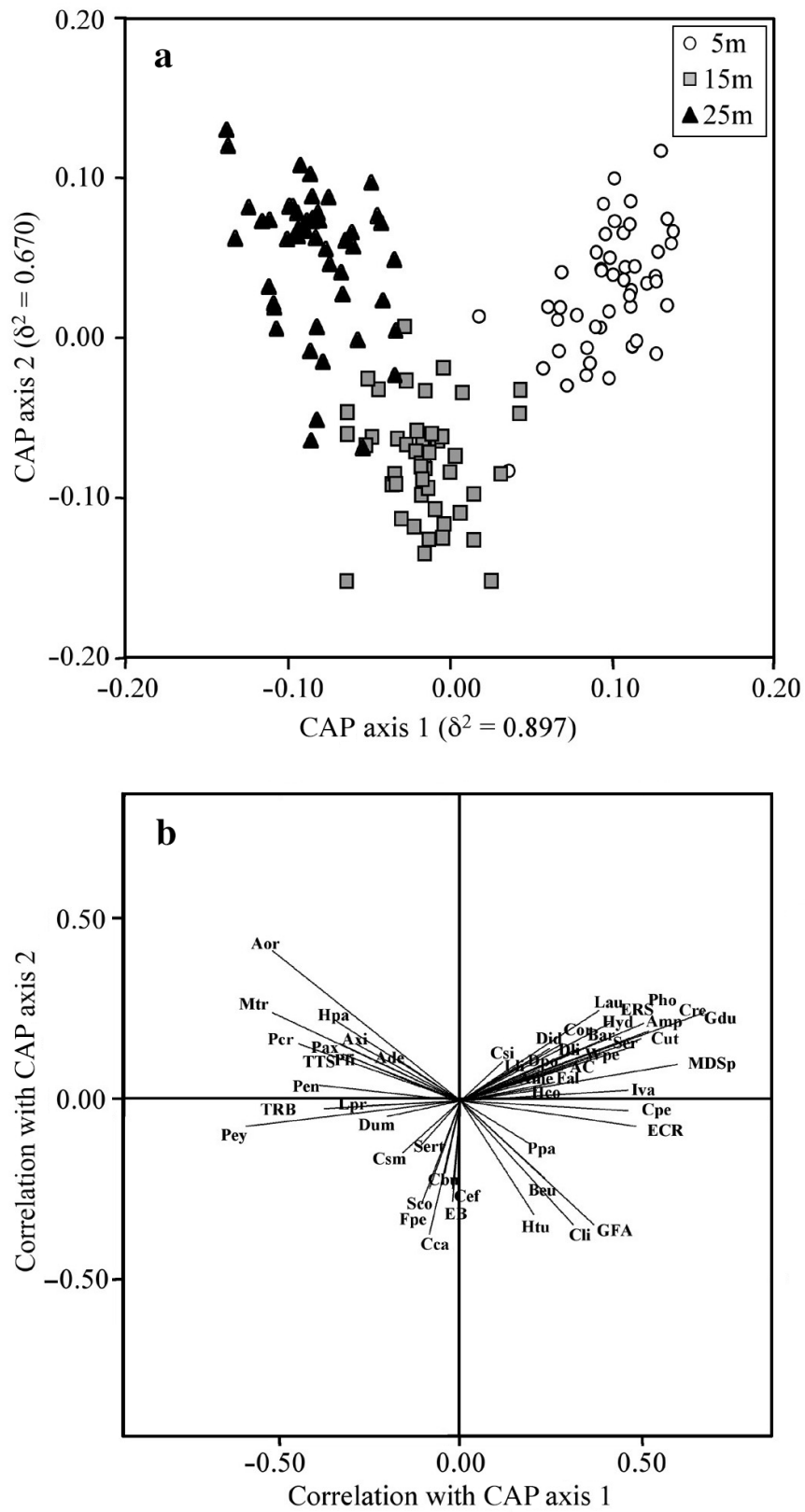

Fig. 4. Canonical analysis of principal coordinates (CAP) plot showing (a) canonical axes that best discriminate assemblages at the 3 different depths and (b) correlations of original taxa variables with the canonical axes. Abbreviations for the taxa in the plot are given in Table 5

Assemblages at $25 \mathrm{~m}$ (arrows pointing to the upper left of the CAP plot, Fig. 4b) were characterised by massive sponges (Agelas oroides, Axinella sp. and Petrosia ficiformis), the anthozoan Parazoanthus axinellae, erect bryozoans (Myriapora truncata, Pentapora sp. and Adeonella sp.) and the ascidian Halocynthia papillosa. A few green (Palmophyllum crassum) and red algae (the thin tubular-like sheet algae) also characterised the assemblage at $25 \mathrm{~m}$ (Fig. $4 \mathrm{~b}$ ). 
Table 5. Definitions (in alphabetic order) of the abbreviations used in Fig. 4b. Full taxonomic details of the variables included in analyses are reported as supplementary material in Appendix 1 (available at www.int-res.com/articles/suppl/ m332p025_app.pdf

\begin{tabular}{|llll|}
\hline Abbr. & Name of variable & Abbr. & Name of variable \\
\hline AC & Articulated corallines & Fpe & Flabellia petiolata \\
Ade & Adeonella sp. & Gdu & Gastrochaena dubia \\
Ame & Ascidia mentula & GFA & Filamentous green algae \\
Amp & Amphiroa spp. & Hco & Hemimycale columella \\
Aor & Agelas oroides & Hpa & Halocynthia papillosa \\
Axi & Axinella sp. & Htu & Halimeda tuna \\
Bar & Balanus perforatus & Hyd & Hydroids \\
Beu & Balanophyllia europaea & Iva & Ircinia variabilis \\
Cbu & Codium bursa & Lau & Laurencia complex \\
Cca & Cladocora caespitosa & Lli & Lithophaga lithophaga \\
Cef & Codium effusum & Lpr & Leptopsammia pruvoti \\
Cli & Cliona spp. & MDSp & Massive dark sponges \\
Cor & Corallina spp. & Mtr & Myriapora truncata \\
Cpe & Cereus pedunculatus & Pax & Parazoanthus axinellae \\
Cre & Chondrosia reniformis & Pcr & Palmophyllum crassum \\
Csi & Colpomenia sinuosa & Pen & Pentapora sp. \\
Csm & Caryophyllia smithii & Pey & Peyssonnelia spp. \\
Cut & Cutleriales & Pfi & Petrosia ficiformis \\
Did & Didemnidae & Pho & Phorbas spp. \\
Dli & Diplosoma listerianum & Ppa & Padina pavonica \\
Dpo & Dictyopteris polypodioides & Sco & Sphaerococcus coronopifolius \\
Dum & Dumontiaceae & Ser & Serpuloidea \\
EB & Encrusting bryozoans & Sert & Sertella sp. \\
ECR & Encrusting calcified Rhodophyta & TRB & Thin ramified bryozoans \\
ERS & Encrusting red sponges & TTS & Thin tubular sheet-like algae \\
FAL & Filamentous algae & Wpe & Wrangelia penicillata \\
& & & \\
& & & \\
\hline
\end{tabular}

At $15 \mathrm{~m}$ (arrows pointing to the lower half of the CAP plot, Fig. 4b), the assemblage was generally characterised by both solitary and colonial anthozoans (Leptosammia pruvoti, Caryophyllia smithii, Balanophyllia europea and Cladocora cespitosa), bryozoans (Sertella sp. and the groups of encrusting and thin ramified bryozoans) and boring sponges of the family Clionidae. The algae Flabellia petiolata, Halimeda tuna and Padina pavonica and some other taxa of red (Peyssonnelia spp., Sphaerococcus coronopifolius and Dumontiaceae) and green algae (Codium effusum, Codium bursa and the group of green filamentous algae) also characterised the assemblage at $15 \mathrm{~m}$ (Fig. 4b).

At $5 \mathrm{~m}$ depth (arrows pointing to the right or upper right of the CAP plot, Fig. 4b), the assemblage was characterised by anthozoans (Cereus pedunculatus), polychaetes (Serpulidae), boring bivalves (Lithophaga lithophaga and Gastrochaena dubia), barnacles, colonial ascidians (Diplosoma listerianum and the family of Didemnidae), hydroids and a diverse set of massive (Ircinia variabilis and the group of massive dark sponges) and encrusting sponges (Hemimycale columella, the species of the genus Phorbas and the species Crambe crambe and Spirastrella cunctatrix, here grouped as encrusting red sponges). A complex suite of both red and brown algae also characterised the assemblage at $5 \mathrm{~m}$. These included encrusting (the brown algae of the order of Cutleriales and a complex suite of encrusting calcified red algae), globose (Colpomenia sinuosa), erect (Dictyopteris polypoides, Wrangelia penicillata), filamentous (the group of filamentous algae) and turf-forming species (Corallina spp., Laurencia complex and the group of articulated corallines including the species Haliptilon virgatum and Jania rubens) (Fig. 4b).

The pseudo multivariate variance components for Time and for $\mathrm{T} \times$ $\mathrm{S}(\mathrm{L})$ were greatest at shallow depths (5 m), regardless of the transformation used, although no significant differences among depths in their relative sizes were detected (Table 6). In contrast, there was no clear pattern of difference among locations (i.e. for the $\mathrm{T} \times \mathrm{L}$ interaction, $5 \mathrm{~m}=15 \mathrm{~m}=25 \mathrm{~m}$, Table 6). In addition, there was greater average variability among locations and among sites at the intermediate depth of $15 \mathrm{~m}$ than at either 25 or $5 \mathrm{~m}$ (Table 6). Interestingly, residual variability among assemblages, from one quadrat to the next, was larger than any other component of variation measured in the study (Fig. 5). Variability among locations was larger than other variance components (apart from the residual) at intermediate depths $(15 \mathrm{~m})$, whereas at depths of 5 and $25 \mathrm{~m}$, variability among sites was the smallest measured variance component (Fig. 5).

Comparisons of the sizes of temporal and spatial variance components among different depths varied, depending on the transformation used. With presence/ absence data, there was significantly greater smallscale variability at the deepest depth $(25 \mathrm{~m})$, followed by the intermediate $(15 \mathrm{~m})$ and then the shallow depth $(5 \mathrm{~m})$. In contrast, with untransformed data, significantly greater residual variability in assemblages was detected at shallower depths $(5 \mathrm{~m}>15 \mathrm{~m}>$ $25 \mathrm{~m}$, Table 6).

\section{Univariate analyses}

Most taxa exhibited heterogeneous distributions, which resulted in many zeros in the data set. Overdispersion prevented the use of traditional univariate 
Table 6. Estimates of multivariate pseudo variance components ( 79 variables) for each term in the model at each of the 3 depths, obtained using the estimators given in Table 1 and the mean squares given in Table 2 . The results of the pairwise comparisons of the estimates using bootstrap $95 \%$ confidence intervals on the differences between each level of depth $(5,15,25 \mathrm{~m})$ are shown in each case as 'test outcome' (data show order of estimates from largest to smallest; inequalities indicate a significant difference at $\mathrm{p}<0.05_{i}=$ indicates no significant differences). No corrections for multiple tests have been applied; T.o. $=$ test outcome

\begin{tabular}{|c|c|c|c|c|}
\hline & Depth & $\begin{array}{c}\text { Bray-Curtis } \\
\text { No transformation }\end{array}$ & $\begin{array}{l}\text { Bray-Curtis } \\
\log (x+1)\end{array}$ & $\begin{array}{l}\text { Bray-Curtis } \\
\text { pres/abs }\end{array}$ \\
\hline Time $=\mathrm{T}$ & $\begin{array}{l}5 \mathrm{~m} \\
15 \mathrm{~m} \\
25 \mathrm{~m} \\
\text { T.o. }\end{array}$ & $\begin{aligned} & 0.0236 \\
& 0.0052 \\
& 0.0040 \\
5 \mathrm{~m}= & 15 \mathrm{~m}=25 \mathrm{~m}\end{aligned}$ & $\begin{aligned} & 0.0184 \\
& 0.0092 \\
& 0.0108 \\
5 \mathrm{~m}= & 15 \mathrm{~m}=25 \mathrm{~m}\end{aligned}$ & $\begin{aligned} & 0.0134 \\
& 0.0097 \\
& 0.0108 \\
5 \mathrm{~m}= & 15 \mathrm{~m}=25 \mathrm{~m}\end{aligned}$ \\
\hline Location = L & $\begin{array}{l}5 \mathrm{~m} \\
15 \mathrm{~m} \\
25 \mathrm{~m} \\
\text { T.o. }\end{array}$ & $\begin{array}{c}0.0283 \\
0.0496 \\
0.0046 \\
5 \mathrm{~m}=15 \mathrm{~m}, 5>25 \mathrm{~m}, 15 \mathrm{~m}>25 \mathrm{~m}\end{array}$ & $\begin{array}{c}0.0182 \\
0.0311 \\
0.0093 \\
5 \mathrm{~m}=15 \mathrm{~m}, 5=25 \mathrm{~m}, 15 \mathrm{~m}>25 \mathrm{~m}\end{array}$ & $\begin{array}{c}0.0103 \\
0.0244 \\
0.0124 \\
5 \mathrm{~m}<15 \mathrm{~m}, 5=25 \mathrm{~m}, 15 \mathrm{~m}>25 \mathrm{~m}\end{array}$ \\
\hline Site $(L)=S(L)$ & $\begin{array}{l}5 \mathrm{~m} \\
15 \mathrm{~m} \\
25 \mathrm{~m} \\
\text { T.o. }\end{array}$ & $\begin{array}{c}0.0050 \\
0.0096 \\
0.0029 \\
5 \mathrm{~m}=15 \mathrm{~m}, 5=25 \mathrm{~m}, 15 \mathrm{~m}>25 \mathrm{~m}\end{array}$ & $\begin{array}{c}0.0059 \\
0.0101 \\
0.0044 \\
5 \mathrm{~m}=15 \mathrm{~m}, 5=25 \mathrm{~m}, 15 \mathrm{~m}>25 \mathrm{~m}\end{array}$ & $\begin{array}{c}0.0047 \\
0.0114 \\
0.0046 \\
5 \mathrm{~m}=15 \mathrm{~m}, 5=25 \mathrm{~m}, 15 \mathrm{~m}>25 \mathrm{~m}\end{array}$ \\
\hline $\mathrm{T} \times \mathrm{L}$ & $\begin{array}{l}5 \mathrm{~m} \\
15 \mathrm{~m} \\
25 \mathrm{~m} \\
\text { T.o. }\end{array}$ & $\begin{aligned} & 0.0095 \\
& 0.0094 \\
& 0.0066 \\
5 \mathrm{~m}= & 15 \mathrm{~m}=25 \mathrm{~m}\end{aligned}$ & $\begin{aligned} & 0.0089 \\
& 0.0106 \\
& 0.0108 \\
5 \mathrm{~m}= & 15 \mathrm{~m}=25 \mathrm{~m}\end{aligned}$ & $\begin{aligned} & 0.0078 \\
& 0.0091 \\
& .0134 \\
5 \mathrm{~m}= & 15 \mathrm{~m}=25 \mathrm{~m}\end{aligned}$ \\
\hline $\mathrm{T} \times \mathrm{S}(\mathrm{L})$ & $\begin{array}{l}5 \mathrm{~m} \\
15 \mathrm{~m} \\
25 \mathrm{~m} \\
\text { T.o. }\end{array}$ & $\begin{array}{c}0.0405 \\
0.0146 \\
0.0130 \\
5 \mathrm{~m}>15 \mathrm{~m}, 5>25 \mathrm{~m}, 15 \mathrm{~m}=25 \mathrm{~m}\end{array}$ & $\begin{aligned} & 0.0281 \\
& 0.0160 \\
& .0157 \\
5 \mathrm{~m}= & 15 \mathrm{~m}=25 \mathrm{~m}\end{aligned}$ & $\begin{aligned} & 0.0199 \\
& 0.0179 \\
& 0.0196 \\
5 \mathrm{~m}= & 15 \mathrm{~m}=25 \mathrm{~m}\end{aligned}$ \\
\hline Residual & $\begin{array}{l}5 \mathrm{~m} \\
15 \mathrm{~m} \\
25 \mathrm{~m} \\
\text { T.o. }\end{array}$ & $\begin{aligned} & 0.1683 \\
& 0.1286 \\
& 0.0814 \\
5 \mathrm{~m}> & 15 \mathrm{~m}>25 \mathrm{~m}\end{aligned}$ & $\begin{array}{c}0.1283 \\
0.1223 \\
0.1162 \\
5 \mathrm{~m}=15 \mathrm{~m}, 5>25 \mathrm{~m}, 15 \mathrm{~m}=25 \mathrm{~m}\end{array}$ & $\begin{array}{c}0.1077 \\
0.1424 \\
0.1625 \\
25 \mathrm{~m}>15 \mathrm{~m}>5 \mathrm{~m}\end{array}$ \\
\hline
\end{tabular}

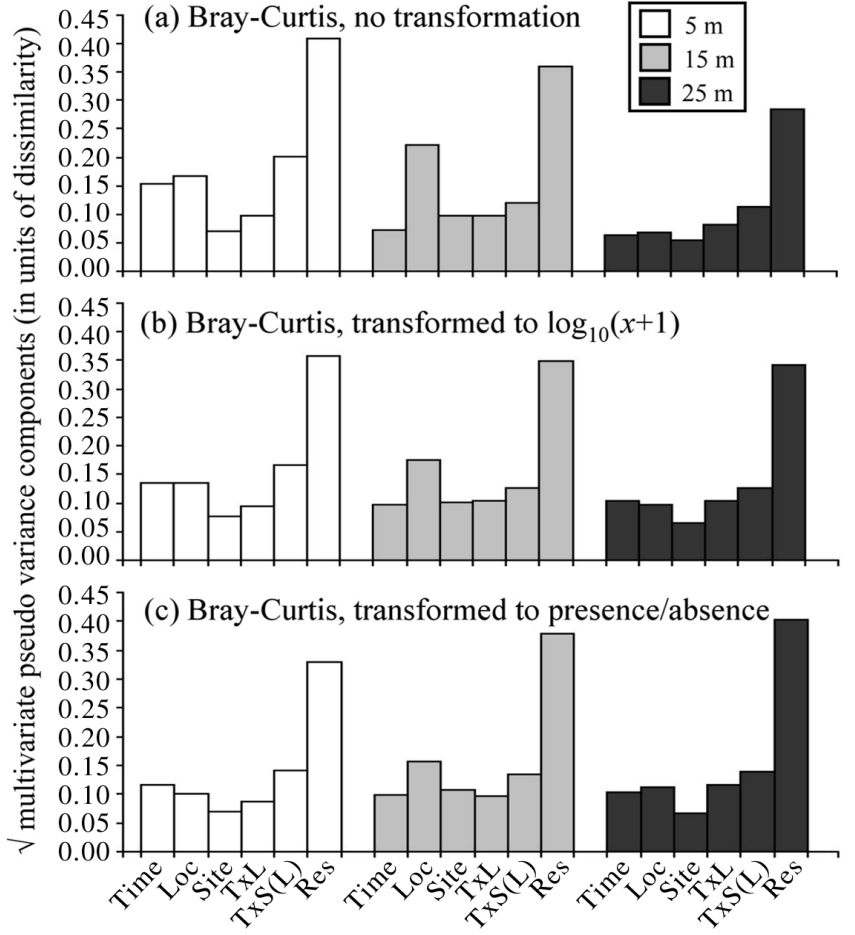

Fig. 5. Multivariate pseudo variance components for different spatial and temporal terms in the model at each of 3 depths. Note that the scale is in the same units as the Bray-Curtis dissimilarity measure analyses on most taxa. Only 5 taxa were common enough to be analysed with ANOVA. In all cases, there were significant $\mathrm{T} \times \mathrm{D} \times \mathrm{S}(\mathrm{L})$ interactions (Table 7 ). This indicated that differences among depths changed interactively in space and time. In order to identify possible patterns within these interactions, mean values were compared across depths within each of the $48 \mathrm{~T} \times$ $\mathrm{S}(\mathrm{L})$ combinations. Of the $48 \mathrm{SNK}$ tests on mean number of taxa, 30 identified clear patterns of differences among depths and in all cases the $5 \mathrm{~m}$ depth was ranked first significantly more often than expected by chance (Anderson test: $Q^{2}=60$, df $=2, \mathrm{p}<0.001$ ). Of the remaining 18 tests, 6 could not distinguish between the $5 \mathrm{~m}$ depth and either the 15 or the $25 \mathrm{~m}$ depths (3 tests in each case), 8 detected no differences and 4 failed to identify a clear alternative to the null hypothesis.

Shallow depths $(5 \mathrm{~m})$ ranked first in terms of mean percent cover of encrusting calcified red algae in 17 out of 23 comparisons, which was statistically significant (Anderson test: $Q^{2}=19.4$, df $=2, p<0.001$ ). It should be noted, however, that of the 48 SNK tests, 17 did not detect any difference among depths, 10 did not distinguish between $5 \mathrm{~m}$ and either $15 \mathrm{~m}$ (8 tests) or $25 \mathrm{~m}$ (2 tests) and 4 did not identify any clear alternative to the null hypothesis. 
Table 7. Results of ANOVAs on spatial and temporal patterns in mean number and mean percentage cover of taxa in the region of study. ${ }^{*} \mathrm{p}<0.05,{ }^{* *} \mathrm{p}<0.01,{ }^{* * *} \mathrm{p}<0.001$. Abbreviations as in Fig. $4 \mathrm{~b}$; see Table 5 for further details. nt: no test

\begin{tabular}{|c|c|c|c|c|c|c|c|c|c|c|c|}
\hline \multirow{2}{*}{$\begin{array}{l}\text { Source of } \\
\text { variation }\end{array}$} & \multirow[t]{2}{*}{$\mathrm{df}$} & \multicolumn{2}{|c|}{ No. of taxa } & \multicolumn{2}{|l|}{ ECR } & \multicolumn{2}{|c|}{ GFA } & \multicolumn{2}{|l|}{ Pey } & \multicolumn{2}{|c|}{ ERS } \\
\hline & & MS & $F$ & MS & $F$ & MS & $F$ & MS & $F$ & MS & $F$ \\
\hline Time $=\mathrm{T}$ & 3 & 594.4 & $5.1^{*}$ & 3.260 & 0.6 & 56.72 & $9.2^{* *}$ & 1526.8 & 1.9 & 0.297 & 0.2 \\
\hline Depth = D & 2 & 1509.7 & $\mathrm{nt}$ & 146.7 & $\mathrm{nt}$ & 82.4 & $\mathrm{nt}$ & 118159.1 & $\mathrm{nt}$ & 48.0 & nt \\
\hline Location $=\mathrm{L}$ & 3 & 95.2 & $\mathrm{nt}$ & 65.5 & $\mathrm{nt}$ & 7.0 & $\mathrm{nt}$ & 21729.2 & $\mathrm{nt}$ & 6.2 & nt \\
\hline $\operatorname{Site}(L)=S(L)$ & 8 & 16.4 & 0.9 & 3.47 & 1.1 & 1.8 & 1.4 & 417.4 & 0.7 & 2.4 & 2.2 \\
\hline $\mathrm{T} \times \mathrm{D}$ & 6 & 36.9 & 2.2 & 9.0 & $2.7^{*}$ & 1.6 & 0.9 & 1777.8 & $3.4^{*}$ & 0.3 & 0.2 \\
\hline $\mathrm{T} \times \mathrm{L}$ & 9 & 117.2 & $6.1^{* * *}$ & 5.4 & 1.7 & 6.1 & $4.8^{* *}$ & 816.1 & 1.4 & 1.2 & 1.1 \\
\hline $\mathrm{T} \times \mathrm{S}(\mathrm{L})$ & 24 & 19.2 & $3.7^{* * *}$ & 3.2 & $4.2^{* * *}$ & 1.3 & $1.9^{* *}$ & 598.1 & $2.7^{* * *}$ & 1.1 & $2.1^{* *}$ \\
\hline $\mathrm{D} \times \mathrm{L}$ & 6 & 59.4 & $\mathrm{nt}$ & 13.1 & nt & 2.3 & $\mathrm{nt}$ & 15704.7 & nt & 6.5 & $\mathrm{nt}$ \\
\hline $\mathrm{D} \times \mathrm{S}(\mathrm{L})$ & 16 & 20.4 & $2.2^{*}$ & 3.4 & 1.4 & 1.4 & 0.9 & 1572.2 & $2.0^{*}$ & 2.5 & $2.9^{* *}$ \\
\hline $\mathrm{T} \times \mathrm{D} \times \mathrm{L}$ & 18 & 16.7 & 1.8 & 3.3 & 1.4 & 1.8 & 1.1 & 531.1 & 0.7 & 1.8 & $2.2^{*}$ \\
\hline $\mathrm{T} \times \mathrm{D} \times \mathrm{S}(\mathrm{L})$ & 48 & 9.4 & $1.8^{* * *}$ & 2.4 & $3.2^{* * *}$ & 1.6 & $2.4^{* * *}$ & 791.4 & $3.6^{* * *}$ & 0.8 & $1.6^{* *}$ \\
\hline Residual & 1296 & 5.2 & & & 0.7 & & 0.7 & 221.0 & & 0.5 & \\
\hline Total & 1439 & & & & & & & & & & \\
\hline Cochran's $C$-test & & $C=0.0239$ & & $C=0.0168$ & & $C=0.0238$ & & $C=0.0237$ & & $C=0.0253$ & \\
\hline Transformation & & None & & $\operatorname{Ln}(x+1)$ & & $\operatorname{Ln}(x+1)$ & & None & & $\operatorname{Ln}(x+1)$ & \\
\hline
\end{tabular}

SNK tests on mean cover of green filamentous algae displayed variable outcomes. Of the 48 tests, 19 did not detect any difference among depths and 6 did not identify any interpretable pattern. Only 16 tests displayed a clear rank of depths. Of these, 15 ranked the $25 \mathrm{~m}$ depth lowest in terms of percent cover of filamentous green algae significantly more often than expected by chance (Anderson test: $Q^{2}=26.4$, df $=2$, $\mathrm{p}<0.001)$. The remaining 7 tests did not distinguish between $25 \mathrm{~m}$ and either $5 \mathrm{~m}$ (4 tests) or $15 \mathrm{~m}$ (3 tests).

Mean percent cover of Peyssonnelia spp. increased with depth. SNK tests identified clear ranks on 32 occasions; among these, the shallow depth $(5 \mathrm{~m})$ was ranked lowest in 29 cases, resulting in a significant pattern of differences (Anderson test: $Q^{2}=47.7, \mathrm{df}=2$, $\mathrm{p}<0.001$ ). Of the remaining SNK tests, 12 did not distinguish between $5 \mathrm{~m}$ and either $15 \mathrm{~m}$ (10 tests) or $25 \mathrm{~m}$ (2 tests), 2 did not detect any difference among depths and 2 did not provide an interpretable result.

SNK tests on mean cover of encrusting red sponges produced clear ranks of depths on 22 out of 48 occasions. Within these tests, 21 ranked the $5 \mathrm{~m}$ depth first-significantly more often than expected by chance (Anderson test: $Q^{2}=38.3, \mathrm{df}=2, \mathrm{p}<0.001$ ). Of the remaining tests, 2 did not detect any difference between $5 \mathrm{~m}$ and either 15 or $25 \mathrm{~m}$ ( 1 test in each case), 18 did not detect any difference at all and 7 failed to identify a sensible alternative to the null hypothesis.

Patterns in spatial and temporal variance differed among depths for all the variables examined (Table 8). Differences occurred at the scales of location, site and replicate, whereas space $\times$ time interactions were consistent among depths. Most of these differences reflected patterns in mean abundance. For example, variance in the number of taxa was larger at shallow depths where mean abundances were also larger. Similarly, variances in percent cover of ECR at the scales of location and replicate were significantly larger at depths of 15 and $5 \mathrm{~m}$, respectively, where these algae were more abundant. Similar patterns of reduction in variance with depth were observed for green filamentous algae and encrusting red sponges. In contrast, Peyssonnelia spp. were consistently and significantly more variable at intermediate depths $(15 \mathrm{~m})$ at the scales of location, site and replicate, though larger values in mean cover were observed at greater depths $(25 \mathrm{~m})$.

\section{DISCUSSION}

This study has described quantitatively the salient patterns of variation in subtidal assemblages along a depth gradient, integrating the use of multivariate and univariate techniques. Overall, there were large and significant differences among depths in the structure of sessile assemblages. Such differences were not independent of species identity, with some taxa being found exclusively at a particular depth. More importantly, differences among depths in assemblage structure varied interactively with time and across the horizontal scales. Overall, subtidal assemblages appeared as a mosaic of patches superimposed on the depth gradient.

Although the relative size of depth effects was variable, the qualitative nature of these effects on sessile assemblages was strong and characterisable in terms of component taxa. This finding is not surprising and concurs with the results of many other studies dealing with depth gradients in subtidal habitats (reviewed by 
Table 8. Summary of results of comparisons of estimates of variance components across depths using bootstrap $95 \%$ confidence intervals of the differences between each level of depth. Only outcomes that were significant and interpretable are shown. Test outcome data show order of estimates from largest to smallest; inequalities indicate a significant difference at $p<0.05$; = indicates no significant differences. No corrections for multiple tests have been applied. Abbreviations as in Fig. $4 \mathrm{~b}$; see Table 5 for further details

\begin{tabular}{|c|c|c|c|c|c|c|}
\hline $\begin{array}{l}\text { Response } \\
\text { variable }\end{array}$ & $\begin{array}{l}\text { Source of } \\
\text { variation }\end{array}$ & Comparison & $\begin{array}{c}\text { Mean } \\
\text { difference }\end{array}$ & $\mathrm{CI}_{\text {low }}$ & $\mathrm{CI}_{\text {high }}$ & Test outcome \\
\hline \multirow[t]{6}{*}{ No. of taxa } & Site(L) & $5 m-15 m$ & 0.017 & -0.345 & 0.365 & \\
\hline & & $5 \mathrm{~m}-25 \mathrm{~m}$ & 0.046 & 0.069 & 0.625 & $5 \mathrm{~m}=15 \mathrm{~m}>25 \mathrm{~m}$ \\
\hline & & $15 \mathrm{~m}-25 \mathrm{~m}$ & 0.029 & 0.109 & 0.571 & \\
\hline & Residual & $5 \mathrm{~m}-15 \mathrm{~m}$ & 1.099 & 0.280 & 2.156 & \\
\hline & & $5 \mathrm{~m}-25 \mathrm{~m}$ & 1.043 & 0.231 & 2.095 & $5 \mathrm{~m}>25 \mathrm{~m}=15 \mathrm{~m}$ \\
\hline & & $15 m-25 m$ & -0.056 & -0.858 & 0.742 & \\
\hline \multirow[t]{6}{*}{ ECR } & Location & $5 m-15 m$ & -1.238 & -69.87 & -23.35 & \\
\hline & & $5 m-25 m$ & 2.444 & -0.992 & 20.37 & $15 \mathrm{~m}>5 \mathrm{~m}=25 \mathrm{~m}$ \\
\hline & & $15 \mathrm{~m}-25 \mathrm{~m}$ & 3.682 & 39.542 & 72.34 & \\
\hline & Residual & $5 \mathrm{~m}-15 \mathrm{~m}$ & 31.256 & 15.554 & 54.335 & \\
\hline & & $5 m-25 m$ & 68.912 & 61.304 & 92.932 & $5 \mathrm{~m}>15 \mathrm{~m}>25 \mathrm{~m}$ \\
\hline & & $15 \mathrm{~m}-25 \mathrm{~m}$ & 37.655 & 29.046 & 54.755 & \\
\hline \multirow[t]{3}{*}{ GFA } & Residual & $5 m-15 m$ & 6.154 & -7.786 & 23.653 & \\
\hline & & $5 \mathrm{~m}-25 \mathrm{~m}$ & 24.951 & 14.426 & 43.383 & $5 \mathrm{~m}=15 \mathrm{~m}>25 \mathrm{~m}$ \\
\hline & & $15 \mathrm{~m}-25 \mathrm{~m}$ & 18.797 & 14.490 & 27.367 & \\
\hline \multirow[t]{9}{*}{ Pey } & Location & $5 \mathrm{~m}-15 \mathrm{~m}$ & -12.899 & -279.884 & -88.584 & \\
\hline & & $5 m-25 m$ & 4.689 & 75.072 & 164.160 & $15 \mathrm{~m}>5 \mathrm{~m}>25 \mathrm{~m}$ \\
\hline & & $15 m-25 m$ & 17.588 & 222.201 & 383.459 & \\
\hline & Site(L) & $5 \mathrm{~m}-15 \mathrm{~m}$ & -1.261 & -51.006 & -17.612 & \\
\hline & & $5 m-25 m$ & -0.212 & -25.272 & 4.516 & $15 \mathrm{~m}>25 \mathrm{~m}>5 \mathrm{~m}$ \\
\hline & & $15 m-25 m$ & 1.049 & 7.060 & 41.839 & \\
\hline & Residual & $5 \mathrm{~m}-15 \mathrm{~m}$ & -125.519 & -182.284 & -98.618 & \\
\hline & & $5 \mathrm{~m}-25 \mathrm{~m}$ & -28.566 & -63.623 & -0.108 & $15 \mathrm{~m}>25 \mathrm{~m}>5 \mathrm{~m}$ \\
\hline & & $15 m-25 m$ & 96.953 & 67.798 & 148.250 & \\
\hline \multirow[t]{6}{*}{ ERS } & Site(L) & $5 m-15 m$ & 0.086 & 0.597 & 1.821 & \\
\hline & & $5 m-25 m$ & 0.124 & 1.206 & 2.269 & $5 \mathrm{~m}>15 \mathrm{~m}>25 \mathrm{~m}$ \\
\hline & & $15 m-25 m$ & 0.038 & 0.255 & 0.776 & \\
\hline & Residual & $5 m-15 m$ & 10.944 & 4.860 & 19.129 & \\
\hline & & $5 m-25 m$ & 12.649 & 7.802 & 20.228 & $5 \mathrm{~m}>15 \mathrm{~m}=25 \mathrm{~m}$ \\
\hline & & $15 m-25 m$ & 1.705 & -5.002 & 8.820 & \\
\hline
\end{tabular}

Witman \& Dayton 2001). Many processes have been proposed as the drivers of these patterns; these processes include changes in light intensity (e.g. Glasby 1999), water movement and sedimentation (Airoldi 2003), salinity (Witman \& Grange 1998), physical (Ayling 1984) and biological disturbance (Ayling 1981, Witman 1985) or the interplay between biotic and abiotic processes (e.g. Smith \& Witman 1999). Such a paradigmatic description of vertical changes has overlooked other important sources of spatial and temporal variation that can interact with these processes (Benedetti-Cecchi 2001, Bussotti et al. 2006).

Spatial variability in the structure of assemblages was relevant at all the scales examined within each of the 3 depths considered. This result indicates that patterns are not invariant to scale, suggests care in generalising the results from small-scale experiments to broader spatial extents (Wootton 2001) and highlights the importance of adopting multi-scale approaches in analyses of spatial patterns (Kotliar \& Wiens 1990, Levin 1992, Hewitt et al. 1998, FowlerWalker \& Connell 2002).

Variability at the spatial scale of hundreds of metres was important in the present study, as it was in other analyses of spatial patterns in marine assemblages (Underwood \& Chapman 1996, Fraschetti et al. 2005b). On rocky substrates, biological effects, such as grazing by sea urchins (Witman 1985) and physical disturbance, such as storm damage (Witman 1987), influence the distribution of sessile assemblages over scales of hundreds of metres. Recruitment is another process structuring subtidal assemblages (e.g. Keough 1983, Gaines \& Bertness 1992), but there is little information relating spatial patterns of assemblages to recruitment over such scales (Smith \& Witman 1999). 
Even less research has been conducted on the changes in the relative importance of recruitment along environmental gradients in the rocky subtidal, despite the wide recognition that such changes are a key component in models of community regulation (Witman \& Grange 1998). The dispersion of larvae, spores and asexual propagules is strongly influenced by water currents and stratification (e.g. Witman \& Dayton 2001). The speed of wave-induced and winddriven streams is dependent on depth, with a pattern of decreasing flow velocity with depth (Denny \& Wethey 2001). Based on these observations, Witman \& Dayton (2001) hypothesized that in temperate environments there is a greater connectivity between sites above than in sites below the thermocline, where populations and assemblages would be less linked by advective transport of larvae and/or propagules. Our results, however, do not support the hypothesis that connectivity among subtidal sessile assemblages decreases with depth, since variability among sites, regardless of the time of sampling, did not clearly increase along the depth gradient.

The largest component of variation occurred at the smallest spatial scale, i.e. among units of observation (centimetres to metres). Variability at the scale of replicates has often been considered a 'statistical nuisance', caused by random processes (Steele 1976). Conversely, multiple, often interacting, ecological processes have been repeatedly demonstrated to affect marine assemblages, also at small scales (Horne \& Schneider 1995). In contrast to intertidal habitats, where small-scale spatial variability has been documented several times (Fraschetti et al. 2005b), patchiness has seldom been documented quantitatively in subtidal habitats (Kennelly \& Underwood 1992). Such information is mostly limited to environmental impact studies (Chapman et al. 1995, Roberts 1996, Terlizzi et al. 2005), where differences in the magnitude of variation among replicate units in disturbed vs. control sites have been suggested as an indicator of environmental impact (Warwick \& Clarke 1993).

Ecological processes potentially important in generating small-scale spatial variability include disturbance (Airoldi 2000, Connell 2005), topographic heterogeneity (Archambault \& Bourget 1999), pre- and post-settlement biological interactions (Sebens 1986, Hunt \& Scheibling 1997) and different patterns of growth depending on life-cycle features (individual vs. modular organisms) (Jackson 1977). Although these processes are pervasive in marine habitats, our results suggest that they may change in magnitude across gradients, since the degree of heterogeneity we observed differed considerably across depths.

Small-scale spatial variability (among replicate quadrats) increased with depth when multivariate ana- lyses were based on presence/absence data, whilst the opposite was observed when abundance data were analysed without transformation. These patterns reflected changes in the scale of aggregation of organisms relative to the size of the sampling unit. Apparently, these relationships were driven by changes in body size of organisms and in number of taxa across depths. Because quadrats were more likely to be dominated by single large organisms in deep waters (e.g. sponges), presence/absence data captured more variability in deep than in shallow assemblages. At shallower depths, in contrast, assemblages were composed of a larger number of small organisms, so that the analyses based on untransformed data captured more variability in shallow than in deep habitats. These results are a clear demonstration of the influence that choices of transformation and sampling design have on our perception of natural patterns of variability in assemblages.

The complexity of spatial patterns and the occurrence of space $\times$ time interactions lead inevitably to greater complexity in the methods needed to deal with variable assemblages. The multivariate methods used here offer several advantages over previously used techniques. First, they require no greater replication of individual observation units than their univariate counterparts in order to achieve a partitioning and independent measure of multivariate variation in the hierarchical design. This contrasts with the method proposed by Underwood \& Chapman (1998), who use separate replication to estimate centroids at each level in the design. Second, the methodology suggested here simply follows the well-known univariate estimation of variance components in an exactly analogous fashion, so it is readily interpretable. Moreover, the measures obtained can be interpreted in terms of the original dissimilarity measure. For those measures which are appropriately scaled (such as the BrayCurtis measure), this means results can be compared both within and across studies.

Bootstrapping of multivariate data to obtain confidence intervals for distance-based criteria has been used in the context of developing multivariate control charts (Anderson \& Thompson 2004). The calculation of distance-based pseudo multivariate variance components has been used by others (Benedetti-Cecchi 2001, Anderson \& Millar 2004, Fraschetti et al. 2005b), although no confidence intervals for such measures have previously been obtained. This is the first time, to our knowledge, that bootstrapping has been used to provide confidence intervals on distance-based pseudo multivariate variance components. This provides a strategy for analysing variability in ecological systems, which is at once flexible (because any distance or dissimilarity measure of choice may be used) and robust 
(because there are no specific assumptions regarding the distribution of the original observation units due to the use of bootstrapping).

Some care is required, however, in the interpretation of results using this approach. First, our results and conclusions are limited to the spatial scales investigated, and different patterns might have emerged by sampling at different spatial resolutions and extents (Andrew \& Mapstone 1987). We made choices in the size of the sampling unit and spatial scales investigated to make our results comparable to those of similar studies conducted in other temperate regions (e.g. Chapman et al. 1995, Roberts 1996). Second, the bootstrapping methodology is not generally unbiased and, as such, some bias-correction is desirable (as was employed here). Third, the results will be heavily dependent on the choice of distance measure and transformation used. This may be an advantage, because it does allow for different aspects of assemblage structure to be captured through the use of different transformations (e.g. Clarke \& Green 1988), and as was also done in the present study. However, this flexibility comes with the responsibility that an appropriate choice be made and correctly interpreted for a given situation. Finally, these 'pseudo' multivariate variance components are not to be thought of as 'true' multivariate variance in the traditional sense. It should be recalled that multivariate variance includes covariance structure among each pair of original variables (e.g. Mardia et al. 1979). Covariance structure, however, is ignored by the distance-based approach. If Euclidean distance is used with one variable, the distance-based procedure will yield the traditional ANOVA variance components. With Euclidean distance and several variables, the distance-based procedure will give the sum of the variances of the original variables. By using some other dissimilarity measure instead, resulting values are not 'variances', but rather are essentially average squared dissimilarities. These measures do, nevertheless, usefully describe the multivariate variation in terms of the chosen dissimilarity measure. Altogether, the univariate and multivariate procedures adopted in the present paper offer a unified framework to describe natural variability in complex habitats like subtidal rocky reefs.

Acknowledgements. Financial support was provided by MIUR (Ministero dell'Università e della Ricerca) in the framework of PRIN (Programmi di Ricerca Scientifica di Rilevante Interesse Nazionale) and FIRB (Fondo per gli Investimenti della Ricerca di Base) projects. The authors acknowledge the support by the MARBEF Network of Excellence 'Marine Biodiversity and Ecosystem Functioning', which is funded in the Community's Sixth Framework Programme (contract no. GOCE-CT-2003-505446). C. Vaglio and P. D'Ambrosio provided many hours of competent diving assistance. L. Matinato and S. Bevilacqua greatly assisted with analysis of the photographic slides and with the preparation of the data matrix. Analyses were performed during a visit by A.T. to the Department of Statistics at the University of Auckland, New Zealand. Thanks to C. Wild, Head of the Department, for providing facilities and space. The final version of this manuscript greatly benefited from comments made by L. Airoldi and P. Archambault.

\section{LITERATURE CITED}

Airoldi L (2000) Responses of algae with different life histories to temporal and spatial variability of disturbance in subtidal reefs. Mar Ecol Prog Ser 195:81-92

Airoldi L (2003) The effects of sedimentation on rocky coast assemblages. Oceanogr Mar Biol Annu Rev 41:161-236

Anderson MJ (2001a) A new method for non-parametric multivariate analysis of variance. Aust Ecol 26:32-46

Anderson MJ (2001b) Permutation tests for univariate or multivariate analysis of variance and regression. Can J Fish Aquat Sci 58:626-639

Anderson MJ, Millar RB (2004) Spatial variation and effects of habitat on temperate reef fish assemblages in north eastern New Zealand. J Exp Mar Biol Ecol 305:191-221

Anderson MJ, Robinson J (2003) Generalised discriminant analysis based on distances. Aust NZ J Stat 45:301-318

Anderson MJ, Thompson AA (2004) Multivariate control charts for ecological and environmental monitoring. Ecol Appl 14:1921-1935

Anderson MJ, Willis TJ (2003) Canonical analysis of principal coordinates: a useful method of constrained ordination for ecology. Ecology 84:511-525

Anderson MJ, Diebel CE, Blom WM, Landers TJ (2005) Consistency and variation in kelp holdfast assemblages: spatial patterns of biodiversity for the major phyla at different taxonomic resolutions. J Exp Mar Biol Ecol 320:35-56

Andrew NL, Mapstone BD (1987) Sampling and the description of spatial pattern in marine ecology. Oceanogr Mar Biol Annu Rev 25:39-90

Archambault P, Bourget E (1999) Influence of shoreline configuration on spatial variation of meroplanktonic larvae, recruitment and diversity of benthic subtidal communities. J Exp Mar Biol Ecol 238:161-184

Ayling AL (1981) The role of biological disturbance in temperate subtidal encrusting communities. Ecology 62:830-847

Ayling AL (1984) Factors affecting the spatial distribution of thinly encrusting sponges from temperate waters. Oecologia 60:412-418

Benedetti-Cecchi L (2001) Variability in abundance of algae and invertebrates at different spatial scales on rocky sea shores. Mar Ecol Prog Ser 215:79-92

Benedetti-Cecchi L, Bertocci I, Micheli F, Maggi E, Fosella T, Vaselli S (2003) Implications of spatial heterogeneity for management of marine protected areas (MPAs): examples from assemblages of rocky coasts in the Northwest Mediterranean. Mar Environ Res 55:429-458

Bishop M, Underwood AJ, Archambault P (2002) Sewage and environmental impacts on rocky shores: necessity of identifying relevant spatial scales. Mar Ecol Prog Ser 236: 121-128

Botsford LW, Micheli F, Hastings A (2003) Principles for the design of marine reserves. Ecol Appl 13:S25-S31

Bussotti S, Terlizzi A, Fraschetti S, Belmonte G, Boero F (2006) Spatial and temporal variability of sessile benthos in shallow Mediterranean marine caves. Mar Ecol Prog Ser 325: 109-116 
Chapman MG, Underwood AJ, Skilleter GA (1995) Variability at different spatial scales between a subtidal assemblage exposed to the discharge of sewage and two control assemblages. J Exp Mar Biol Ecol 189:103-122

Clarke KR, Green RH (1988) Statistical design and analysis for a 'biological effects' study. Mar Ecol Prog Ser 46:213-226

Connell S (2005) Assembly and maintenance of subtidal habitat heterogeneity: synergistic effects of light penetration and sedimentation. Mar Ecol Prog Ser 289:53-61

Davison AC, Hinkley DV (1997) Bootstrap methods and their application. Cambridge University Press, Cambridge, p 100-102

Denny M, Wethey D (2001) Physical processes that generate patterns in marine communities. In: Bertness MD, Gaines SD, Hay ME (eds) Marine community ecology. Sinauer Associates, Sunderland, MA, p 3-37

Dethier MN, Graham ES, Cohen S, Tear LM (1993) Visual versus random-point percent cover estimations: 'objective' is not always better. Mar Ecol Prog Ser 96:93-100

Efron B, Tibshirani RJ (1993) An introduction to the bootstrap. Chapman \& Hall, New York

Fowler-Walker MJ, Connell SD (2002) Opposing states of subtidal habitat across temperate Australia: consistency and predictability in kelp canopy-benthic associations. Mar Ecol Prog Ser 240:49-56

Fletcher DJ, Underwood AJ (2002) How to cope with negative estimates of components of variance in ecological field studies. J Exp Mar Biol Ecol 273:89-95

Fraschetti S, Bianchi CN, Terlizzi A, Fanelli G, Morri C, Boero F (2001) Spatial variability and human disturbance in shallow subtidal hard substrate assemblages: a regional approach. Mar Ecol Prog Ser 212:1-12

Fraschetti S, Terlizzi A, Bussotti S, Guarnieri G, D'Ambrosio P, Boero F (2005a) Conservation of Mediterranean seascapes: analyses of existing protection schemes. Mar Environ Res 59: $309-332$

Fraschetti S, Terlizzi A, Benedetti-Cecchi L (2005b) Patterns of distribution of rocky marine assemblages: evidence of relevant scales of variation. Mar Ecol Prog Ser 296:13-29

Fraschetti S, Terlizzi A, Bevilacqua S, Boero F (2006) The distribution of hydroids (Cnidaria, Hydrozoa) from micro- to macro-scale: Spatial patterns on habitat-forming algae. J Exp Mar Biol Ecol 339:148-158

Gaines SD, Bertness MD (1992) Dispersal of juveniles and variable recruitment in sessile marine species. Nature 360:579-580

Glasby TM (1999) Effects of shading on subtidal epibiotic assemblages. J Exp Mar Biol Ecol 234:275-290

Hewitt JE, Thrush SF, Cummings VJ, Turner SJ (1998) The effect of changing sampling scales on our ability to detect effects of large-scale processes on communities. J Exp Mar Biol Ecol 227:251-264

Horne JK, Schneider DS (1995) Spatial variance in ecology. Oikos 74:18-26

Hunt HL, Scheibling RE (1997) Role of early post-settlement mortality in recruitment of benthic marine invertebrates. Mar Ecol Prog Ser 155:269-301

Hurlbert SH (1984) Pseudoreplication and the design of ecological experiments. Ecol Monogr 54:187-211

Jackson JBC (1977) Competition on marine hard substrata: the adaptive significance of solitary and colonial strategies. Am Nat 111:743-767

Kennelly SJ, Underwood AJ (1992) Fluctuations in the distribution and abundances of species in sublittoral kelp forests in New South Wales. Aust J Ecol 17:367-382

Keough MJ (1983) Patterns of recruitment of sessile invertebrates in two subtidal habitats. J Exp Mar Biol Ecol 66:213-245
Kotliar NB, Wiens JA (1990) Multiple scales of patchiness and patch structure: a hierarchical framework for the study of heterogeneity. Oikos 59:253-260

Lawton JH (1996). Patterns in ecology. Oikos 75:145-147

Legendre P, Anderson MJ (1999) Distance-based redundancy analysis: testing multispecies responses in multifactorial ecological experiments. Ecol Monogr 69:1-24

Legendre P, Fortin MJ (1989) Spatial pattern and ecological analysis. Vegetatio 80:107-138

Levin SA (1992) The problem of pattern and scale in ecology. Ecology 73:1943-1967

Mardia KV, Kent JT, Bibby JM (1979) Multivariate analysis. Academic Press, New York

McArdle BH, Anderson MJ (2001) Fitting multivariate models to community data: a comment on distance-based redundancy analysis. Ecology 82:290-297

Pérès JM (1982) Major benthic assemblages. In: Kinne O (ed) Marine ecology, Vol 5, Part 1. Wiley \& Sons, London, p 373-508

Perry NJ, Liebhold AM, Rosenberg MS, Dungan J, Miriti M, Jakomulska A, Cistron-Pousty S (2002) Illustrations and guidelines for selecting statistical methods for quantifying spatial patterns in ecological data. Ecography 25:578-600

Riedl R (1971) Water movement: animals. In: Kinne O (ed) Marine ecology, Vol 1, Part 2. Wiley \& Sons, London, p 1123-1156

Roberts DE (1996) Patterns in subtidal marine assemblages associated with a deep-water sewage outfall. Mar Freshw Res 47:1-9

Rossi RE, Mulla DJ, Journel AG, Franz EH (1992) Geostatistical tools for modeling and interpreting ecological spatial dependence. Ecol Monogr 62:277-314

Sarà M (1969) Research on coralligenous formations: problems and perspectives. PSZN I: Mar Ecol 37:124-134

Searle SR, Casella G, McCulloch GE (1992) Variance components. Wiley, New York

Sebens KB (1986) Spatial relationships among encrusting marine organisms in the New England subtidal zone. Ecol Monogr 56:73-96

Smith F, Witman JD (1999) Species diversity in subtidal landscapes: maintenance by physical processes and larval recruitment. Ecology 80:51-69

Southward AJ (1958) The zonation of plants and animals on rocky sea shores. Biol Rev 33:137-177

Steele JH (1976) Patchiness. In Cushing DH, Walsh JJ (eds) Ecology of the sea. Blackwell, London, p 98-115

Stephenson TA, Stephenson A (1949) The universal features of zonation between the tidemarks on rocky coasts. J Ecol 38:289-305

Terlizzi A, Benedetti-Cecchi L, Bevilacqua S, Fraschetti S, Guidetti P, Anderson MJ (2005) Multivariate and univariate asymmetrical analyses in environmental impact assessment: a case study of Mediterranean subtidal sessile assemblages. Mar Ecol Prog Ser 289:27-42

Underwood AJ (2000) Experimental ecology on rocky intertidal habitats: What are we learning? J Exp Mar Biol Ecol 250:51-76

Underwood AJ, Chapman MG (1996) Scales of spatial patterns of distribution of intertidal invertebrates. Oecologia 107:212-224

Underwood AJ, Chapman MG (1998) A method for analysing spatial scales of variation in composition of assemblages. Oecologia 117:570-578

Underwood AJ, Chapman MG, Connell SD (2000) Observation in ecology: you can't make progress on processes without understanding the patterns. J Exp Mar Biol Ecol 250:97-115 
Underwood AJ, Petraitis PS (1993) Structure of intertidal assemblages in different locations: how can local processes be compared? In: Ricklefs R, Schutler D (eds) Species diversity in ecological communities. University of Chicago Press, Chicago, IL, p 38-51

Virgilio M, Airoldi L, Abbiati M (2006) Spatial and temporal variations of assemblages in a Mediterranean coralligenous reef and relationships with surface orientation. Coral reefs 25:265-272

Warwick RM, Clarke KR (1993) Increased variability as a symptom of stress in marine communities. J Exp Mar Biol Ecol 172:215-226

Wiens JA, Stenseth NC, Van Horne B, Ims RA (1993) Ecological mechanisms and landscape ecology. Oikos 66:369-380

Winer BJ, Brown DR, Michels KM (1991) Statistical principles in experimental designs, 3rd edn. McGraw-Hill, Sydney

Editorial responsibility: Roger Hughes (Contributing Editor), Bangor, UK
Witman JD (1985) Refuges, disturbance and rocky subtidal community structure in New England. Ecol Monogr 55: 421-445

Witman JD (1987) Subtidal coexistence: storms, grazing, mutualism, and the zonation of kelps and mussels. Ecol Monogr 57:167-187

Witman JD, Dayton PK (2001) Rocky subtidal communities. In: Bertness MD, Gaines SD, Hay ME (eds) Marine community ecology. Sinauer Associates, Sunderland, MA, p 339-366

Witman JD, Grange KR (1998) Links between rain, salinity, and predation in a rocky subtidal community. Ecology 79:2429-2447

Wootton JT (2001) Local interactions predict large-scale pattern in empirically derived cellular automata. Nature 413: $841-843$

Submitted: May 16, 2006; Accepted: August 16, 2006

Proofs received from author(s): February 13, 2007 